\title{
Epithelioid Cell Type Gastrointestinal Stromal Tumor
}

National Cancer Institute

\section{Source}

National Cancer Institute. Epithelioid Cell Type Gastrointestinal Stromal Tumor. NCI

Thesaurus. Code C3486.

A benign or malignant gastrointestinal stromal tumor with epithelioid morphology.. 